\title{
Predicting size at first sexual maturity from length/weight relationship: a case study with an Amazonian catfish
}

\author{
Tiago Magalhães da Silva Freitas ${ }^{1}$, Vitor Hudson da Consolação Almeida², Luciano \\ Fogaça de Assis Montag ${ }^{3}$, Nelson Ferreira Fontoura ${ }^{4}$
}

Relationship between length and weight (LWR) is used to describe aspects concerning the life cycle of fish, but does not considers possible changes during the lifetime mainly due to the sexual maturation. Thus, this study aims to identify the size at first maturity of Auchenipterichthys longimanus (Siluriformes: Auchenipteridae) and infer if the reproductive engagement could change growth pattern, concerning the LWR. Estimates of the size at first maturity $\left(L_{50}\right)$ were made by visual identification of gonadal development and through the gonadosomatic index $\left(G_{\mathrm{SI}}\right) . L_{50}$ was estimated as $12.5 \mathrm{~cm}$ for males and $13.0 \mathrm{~cm}$ for females when applied visual identification of gonads development. $L_{50}$ estimates increased to 13.05 $\mathrm{cm}$ for males and $13.7 \mathrm{~cm}$ for females when estimated from $\mathrm{G}_{\mathrm{SI}}$ values. LWR was adjusted by using a regular power function and through the polyphasic growth model, with proportionality and allometric coefficients changing in a two phases. The results indicate differences in the growth pattern concerning males and females, as well as polyphasic growth. The change in the growth pattern of the polyphasic LWR was estimated at $11.42 \mathrm{~cm}$ for males and $12.53 \mathrm{~cm}$ for females, suggesting that changes in the growth pattern can sign-out the attainment maturity in this catfish.

O estudo da relação entre peso e comprimento é usado para investigar muitos aspectos do ciclo de vida dos peixes, mas não considera que o padrão de crescimento pode mudar durante o tempo vida, principalmente devido à maturação sexual. Desta forma, este estudo objetivou identificar o tamanho de primeira maturação do bagre Auchenipterichthys longimanus (Siluriformes: Auchenipteridae) e testar se início do engajamento reprodutivo pode ser responsável por mudanças no padrão de crescimento da espécie, concernindo à relação peso/comprimento. Estimativas de tamanho de primeira maturação sexual $\left(L_{50}\right)$ foram realizadas por meio da identificação visual dos estágios de maturação e pelos valores do Índice Gonadossomático (IGS). $\mathrm{O} L_{50}$ foi estimado em $12,5 \mathrm{~cm}$ para machos e $13,0 \mathrm{~cm}$ para fêmeas quando aplicados a identificação visual dos estágios de maturação. A estimativa do $L_{50}$ aumentou para $13,05 \mathrm{~cm}$ para machos e $13,7 \mathrm{~cm}$ para fêmeas quando aplicados os valores de IGS. A relação peso/comprimento foi ajustada utilizando uma função potência e pelo modelo de crescimento polifásico, com coeficientes de proporcionalidade e alométrico diferentes para duas fases. Os resultados indicam diferenças no padrão de crescimento de machos e fêmeas, além de um crescimento polifásico para ambos os sexos. A mudança no padrão de crescimento foi estimada em $11,42 \mathrm{~cm}$ para machos e $12,53 \mathrm{~cm}$ para fêmeas, sugerindo que essas mudanças podem estar associadas ao início da vida reprodutiva desse bagre.

Keywords: Amazonia, Auchenipteridae, Fish reproduction, Growth pattern, Sexual maturity.

\section{Introduction}

The relationship between body length and weight is used since the late 19th century to depict many aspects concerning the life cycle of fish (see Le Cren, 1951; Froese, 2006), and is described following the equation proposed by Huxley (1924), $W=a^{*} L^{b}$. This model considers that the body proportions increase according to a constant, $b$, defined as the coefficient of allometry. As usually applied, this parameter is kept constant during the animal's entire life cycle, without taking account any possible change in the growth pattern due to ontogeny (Swain \& Foote, 1999).

\footnotetext{
${ }^{1}$ Universidade Federal do Pará (UFPA), Campus Universitário do Marajó-Breves, Faculdade de Ciências Naturais, Alameda IV, No 3418 - Parque Universitário. 68.800-000 Breves, PA, Brazil. freitastms@gmail.com (corresponding author)

${ }^{2}$ Coordenação de Gestão Ambiental, Núcleo de Gerenciamento de Transporte Metropolitano - NGTM. Av. Gentil Bittencourt, 1539, Nazaré, 66.040-172 Belém, PA, Brazil. vitor.amazonia@gmail.com

${ }^{3}$ Universidade Federal do Pará (UFPA), Laboratório de Ecologia e Conservação, Instituto de Ciências Biológicas, Rua Augusto Corrêa, 01, Guamá, 66.075-110 Belém, PA, Brazil.1famontag@gmail.com

${ }^{4}$ Pontifícia Universidade Católica do Rio Grande do Sul (PUCRS), Faculdade de Biociências. Av. Ipiranga, 6681, $90619-900$ Porto Alegre, RS, Brazil.nfontoura@pucrs.br
} 
Huxley (1924) himself identified this potential problem, which was subsequently referred to as polyphasic allometry by Strauss (1993). Based on this approach, Bervian et al. (2006) proposed a mathematical model that considers possible variation in individual growth patterns over time. This model divides the growth process into stanzas, or growth phases, each one with unique values of $a$ and $b$, depending on specific ontogenetic and environmental drivers.

Using this model, Bervian et al. (2006) identified a change in the growth pattern related to the attainment of sexual maturity for Micropogonias furnieri (Desmarest, 1823) (Perciformes). This same approach was applied to determine if the length/weight relationship of Characid fish species were also signifying reproductive engagement through a change in the growth pattern (Fontoura et al., 2010). Although with no direct estimated size at first sexual maturity, the later authors identified that the middle point between two distinct growth phases (stanzas) were similar to published values of size at first maturity, or at least, to size at sexual maturity estimated by the general model proposed by Froese \& Binohlan (2000).

Considering that fishes can change its growth pattern during the lifetime, and that many authors indicate this could sign-out the beginning of the reproduction engagement (Bervian et al. 2006; Fontoura et al., 2010), the aim of the present work is to establish the length/ weight relationship for a siluriform fish species in an attempt to verify possible changes in growth pattern and its relation to the size of the first gonadal maturation. The change in the coefficient of allometry was compared with two distinct models for the estimation of the size at first sexual maturity: (1) classification of developmental stages of the gonads and (2) values of the gonadosomatic index. The species used as model was Auchenipterichthys longimanus (Günther, 1864), a Neotropical endemic catfish belonging to the family Auchenipteridae, with wide distribution in the Amazon and Orinoco basins (Ferraris et al., 2005).

\section{Material and Methods}

Data collection and processing. Samples of Auchenipterichthys longimanus were collected every two months between July 2008 and July 2009 in rivers of the Caxiuanã National Forest (145'27.5”S, 51 $\left.27^{\circ} 33.2^{\prime \prime} \mathrm{W}\right)$, a protected area located in eastern Amazonia, Brazil (Fig. 1).

Specimens were collected using $100 \mathrm{~m}$ gillnets with a height of $1.5 \mathrm{~m}$, and mesh sizes between $3 \mathrm{~cm}$ and $6 \mathrm{~cm}$ opposites knots. The nets were set for six hours per day at locations selected with the help of a local fisherman. Once captured, the specimens of $A$. longimanus were measured (total length, to nearest $0.1 \mathrm{~cm}$ ), weighed (body weight, to nearest $0.1 \mathrm{~g}$ ) and eviscerated for gonadal removal, which were also weighed (to nearest $0.001 \mathrm{~g}$ ).

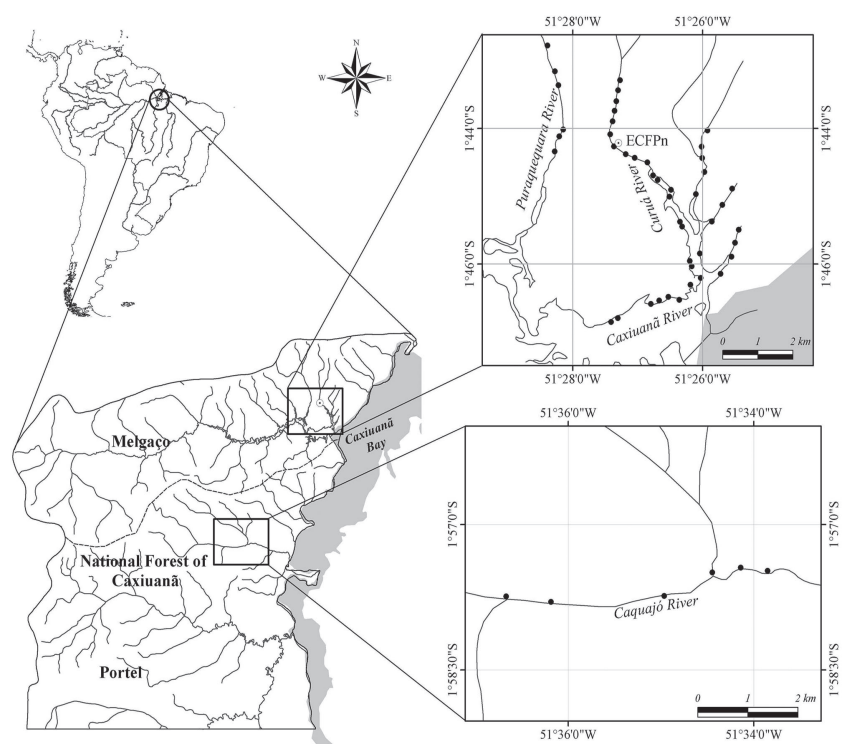

Fig. 1. Sampling area in the National Forest of Caxiuanã, Pará State, showing the rivers where the fish were collected; Curuá River - Ferreira Penna Research Station (ECFPn), Caxiuanã River; Puraquequara River and Caquajó River. A single point on the map may represent more than one colleting site.

Sexual maturity was visually classified by gonad examination, following Vazzoler (1981): stage I (immature); gonads of reduced size, translucent, located adjacent to the vertebral column; stage II (maturing); gonads occupying a third of the abdominal cavity with well-developed capillary network; stage III (mature); gonads turgid, occupying the majority of the abdominal cavity (in the females, the oocytes are visible to the naked eye, while in the males, the testes are whitish); and stage IV (at rest or empty); gonad completely flaccid with a hemorrhagic aspect.

Voucher specimens are deposited in the ichthyological collection of the Emílio Goeldi Museum (MPEG) in Belém, Pará, registered under the numbers MPEG 1525715259, MPEG 15260-15264, MPEG 15432-15442, MPEG 15498-15507, MPEG 15544-15555, MPEG 15844-15860, and MPEG 16221-16231.

\section{Data analyses}

The analyses consisted in three different approaches and were made for each sex: (1) the establishment of the length/weight relationship and (2) the size at first sexual maturity using two distinct models: (A) visual identification of gonads development $\left(\mathrm{L}_{50}\right.$ Maturity Scale) and (B) values of the gonadosomatic index $\left(G_{\mathrm{SI}}\right.$ - the weight of the gonads as a percentage of the total weight of the fish; $\mathrm{L}_{50} \mathrm{G}_{\mathrm{SI}} \%$ ).

The length/weight relationship for $A$. longimanus following the Huxley's original allometric equation $\left(y=a \cdot x^{b}\right)$ was performed using the Solver routine of the Microsoft 
Office Excel ${ }^{\mathbb{2} 2007}$ software (Newton search algorithm). Considering the heterocedasticity of the residual pattern, the least squares of proportional residues ([observedpredicted]/predicted) were applied as Loss function. In order to identify sex differences concerning growth pattern, the function was initially adjusted to merged sex, comparing males and females residuals with $t$ test $(5 \%$ of significance), following a methodological approach proposed by Fontoura \& Conter (2008) to compare morphometric measurements.

The existence of non-random patterns in the residuals of $y$ (weight) in relation to $x$ (length) was evaluated through linear/polynomial regressions and $\mathrm{F}$ tests for regression significance (Zar, 2009). Once any anomaly in residual distribution was identified, the application of the polyphasic adjustment proposed by Bervian et al. (2006) was performed.

The polyphasic model is a modified power equation, using a logistic function for the parameters $a$ and $b$ of Huxley (1924): $y=f(a) \cdot x^{f(b)}$, where $f(a)=a_{1}+\left(a_{2}-a_{1}\right) /\left(1+e^{R s c(a) \cdot(x-L s c)}\right.$, and $f(b)=b_{1}+\left(b_{2}-b_{1}\right) /\left(1+e^{R s c(b) \cdot(x-L s c)}\right)$, and $a_{1}$ and $b_{1}$ are the coefficients of proportionality and allometry determined in the first stanza, and $a_{2}$ and $b_{2}$ are the same coefficients determined in the second stanza, $R_{s c}(a / b)$ is the rate of change of the coefficients between stanzas 1 and 2, and $L_{s c}$ is the length at the stanza changing point.

The polyphasic function was adjusted using the Solver routine available in the Microsoft Excel ${ }^{\circledR 2007}$ program (loss function using least squares of proportional residues, Newton search algorithm). Considering the lack of a clear point of change based on the residual distribution, the full data set was divided into two sub-samples. The first sub-sample comprised all sizes from the smaller captured individual to the half of length range, and a second subsample comprising all the captured individuals from the half of length range to the larger individual. Then, a preliminary weight/length relationship was adjusted independently for each data sub-sample. The coefficients of allometry and proportionality of each of these preliminary stanzas were then used as seed values for the adjustment of the complete function. In this case, in the absence of known biological data, the rate of change $R_{s c}(a / b)$ was assigned with an initial value of 1.0, while the stanza changing length $\left(L_{s c}\right)$ was defined as $12 \mathrm{~cm}$, after a preliminary visual analysis of the residual pattern for females. The coefficient of determination was calculated as the ratio between the sum of the squares of the residuals and the total sum of squares (Zar, 2009). The $P$ values were obtained by testing the significance of the coefficient of determination, using the F statistic, with a significance level of 5\% (Zar, 2009).

For both estimation of size at first sexual maturity $\left(\mathrm{L}_{50}\right.$ Maturity Scale or $\mathrm{L}_{50} \mathrm{GSI} \%$ ) the individuals were binarized as non-reproductive or reproductive. In the $\mathrm{L}_{50}$ Maturity Scale specimens in gonadal development stages II, III, and IV were assigned as reproductive. The other method, the $G_{\mathrm{SI}}$ values were transformed into a percentage of the maximum value recorded for the species. As proposed by Fontoura et al. (2009), all individuals with $G_{\mathrm{SI}}$ values equal to or greater than $10 \%$ of the maximum recorded value for A. longimanus were considered as engaged in the reproductive process.

For both methods the following equation was applied: $P=A^{*}\left(1+e^{r \cdot(L t-L 50)}\right)^{-1} ;$ where $P=$ the proportion of reproductive/ adult individuals for each size class; $A=$ the asymptote of the curve; $r=$ rate of change between the non-reproductive and the reproductive phase; $L_{\mathrm{t}}=$ total length $(\mathrm{cm})$, and $L_{50}$ $=$ size at fist sexual maturity, the estimated size $(\mathrm{cm})$ at which $50 \%$ of the individuals have reached maturity. In the approach based on the scale of maturity, $A=1.0$. For these methods, the equation parameters were estimated with the data set organized in $0.5 \mathrm{~cm}$ length classes by using non-linear functions in the SPSS ${ }^{\circledR} 17.0$ software package (Levenberg-Marquardt algorithm).

\section{Results}

A total of 564 specimens of A. longimanus (235 males and 329 females) were analyzed. Males were slightly smaller and lighter than females ( $\mathrm{p}<0.001$ for both total length and body weight). Mean total length for males was $13.2 \pm 2.05$ $\mathrm{cm}(\min =7.3 \mathrm{~cm} ; \max =18.8 \mathrm{~cm})$, while in females, it was $13.9 \pm 2.02 \mathrm{~cm}(\min =8.5 \mathrm{~cm} ; \max =19.1 \mathrm{~cm})$. Mean weight for males $(34.3 \pm 15.8 \mathrm{~g} ; \min =5.0 \mathrm{~g} ; \max =91.0 \mathrm{~g})$ was also lower than that for females $(42.7 \pm 18.5 \mathrm{~g}$; $\min =7.0 \mathrm{~g}$; $\max$ $=110.0 \mathrm{~g}$ ).

By comparing residuals of the combined length/weight relationship, a clear difference among males and females was identified $(p<0.001)$. The adjustment of the length/weight relationship for males using the single phase Huxley model (Fig. 2a) resulted in a non-random residual distribution (Fig. 2c). The non-randomness of this arrangement was tested by using a linear regression of the residuals as a function of total length $(x)$, which resulted in significant angular coefficient $(p<0.001)$. For males the single-phase model of the length/weight relationship was inadequate (Fig. 2b; Table 1), and the Bervian et al. (2006) polyphasic model was applied, which resulted in no residual trend (Fig. 2d; p $=0.999)$. The stanza changing length $\left(L_{s c}\right)$ was estimated as $11.4 \mathrm{~cm}$. Individuals below this size presented a negatively allometric growth pattern $(b=2.88)$, while those above this size were characterized by positive allometry $(b=3.18)$.

For females, residuals derived from the single-phase length/weight relationship presented a more complex behavior, being described by a second-order polynomial regression (Fig. 3c; p = 0.038). After a polyphasic adjustment (Fig. 3b; Table 1), a random distribution of the residuals was obtained (Fig. 3d), for which a linear regression of the residuals indicated no trend $(p=0.672)$. The stanza changing length $\left(L_{s c}\right)$ was estimated as $12.5 \mathrm{~cm}$, below which individuals presented a positive allometric growth pattern $(b=3.22)$, whereas larger individuals are characterized by negative allometry $(b=2.95)$. 

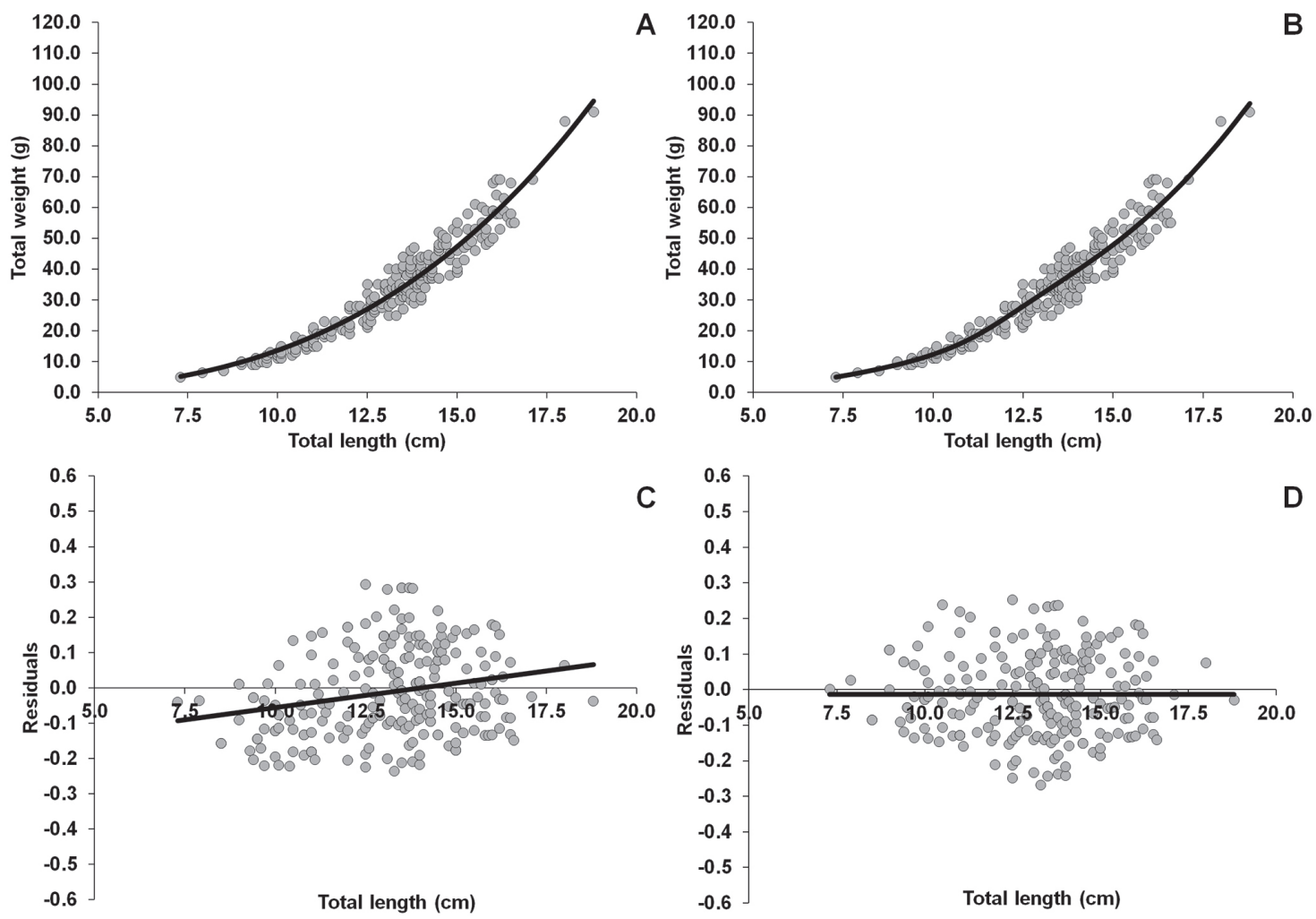

Fig. 2. Length/weight relationship of male Auchenipterichthys longimanus. A and C represent Huxley regular length/weight relationship and its distribution of proportional residuals. B and D represent polyphasic length/weight relationship its and distribution of proportional residuals.
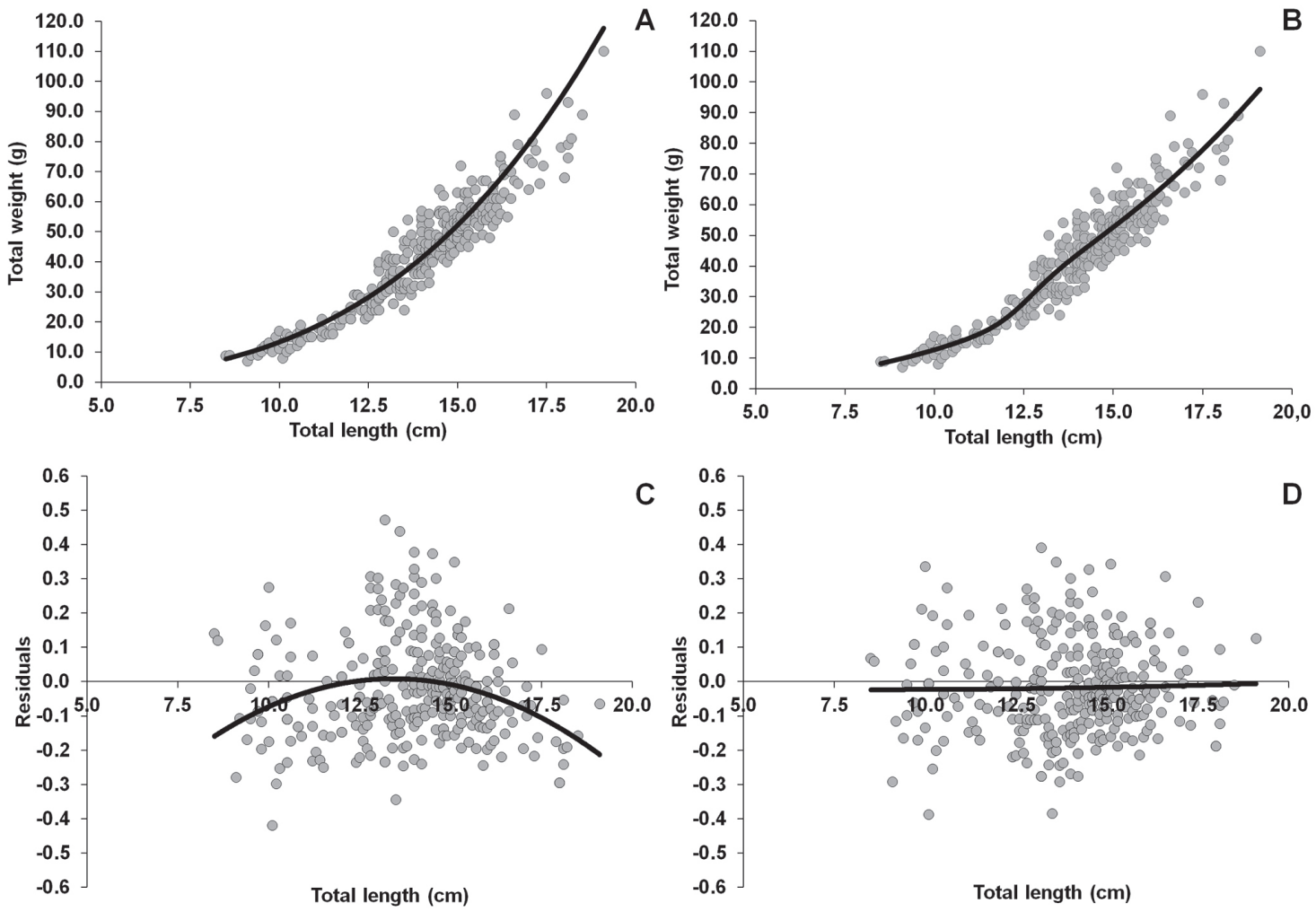

Fig. 3. Length/weight relationship of female Auchenipterichthys longimanus. A and C represent Huxley regular length/ weight relationship and its distribution of proportional residuals. B and D represent polyphasic length/weight relationship its and distribution of proportional residuals. 
Table 1. Parameters obtained for the length/weight relationship for Auchenipterichthys longimanus by the adjustments to the single-phase and polyphasic models.

\begin{tabular}{cccc}
\hline Model & Parameter & Males & Females \\
\hline \multirow{3}{*}{ Single phase } & $a$ & 0.012 & 0.006 \\
& $b$ & 3.06 & 3.36 \\
& Sum of the residuals & 3.552 & 6.928 \\
& $a 1$ & 0.017 & 0.010 \\
& $a 2$ & 0.008 & 0.014 \\
Polyphasic & $b 1$ & 2.88 & 3.22 \\
& $b 2$ & 3.18 & 2.95 \\
& $R_{s c}(a)$ & 0.721 & -2.332 \\
& $R_{s c}(b)$ & -1.082 & 0.191 \\
& $L_{s c}($ crm $)$ & 11.4 & 12.5 \\
& Sum of the residuals & 3.070 & 5.951 \\
\hline$\ldots \ldots \ldots \ldots \ldots$
\end{tabular}
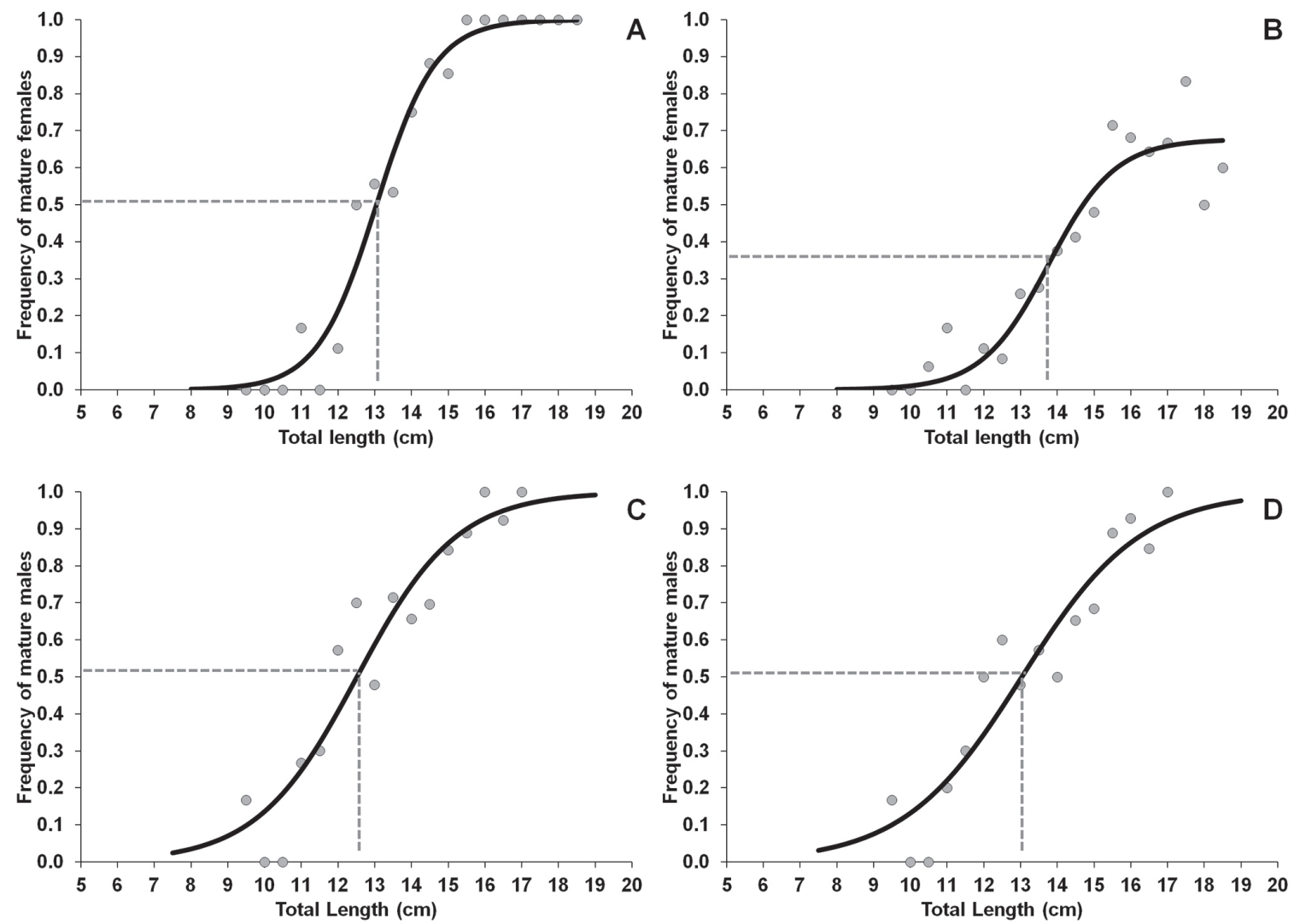

Fig. 4. Frequency of mature individuals as a function of the total length. Female sexual maturity identified by visual inspection of ovarian (A) and $G_{\mathrm{SI}}$ values (B). Male sexual maturity identified by visual inspection of testes (C) and $G_{\mathrm{SI}}$ values (D).

Table 2. Parameters obtained for the estimate of size at first sexual maturity in Auchenipterichthys longimanus using the maturity scale and gonadosomatic index $\left(G_{\mathrm{SI}}\right)$ approaches.

\begin{tabular}{|c|c|c|c|c|c|c|}
\hline \multirow{2}{*}{ Sex } & \multirow{2}{*}{ Parameter } & \multirow{2}{*}{ Estimate $(\mathrm{cm})$} & \multirow{2}{*}{ Asymptote } & \multirow{2}{*}{ Standard error } & \multicolumn{2}{|c|}{ 95\% Confidence interval } \\
\hline & & & & & Lower limit & Upper limit \\
\hline \multirow{3}{*}{ Male } & $L_{s c}$ & 11.42 & - & - & - & - \\
\hline & $L_{50}$ (Maturity Scale) & 12.51 & 1 & 0.244 & 11.99 & 13.05 \\
\hline & $L_{50}\left(G_{\mathrm{SI}} \%\right)$ & 13.03 & 0.997 & 0.675 & 11.28 & 14.22 \\
\hline \multirow{3}{*}{ Female } & $L_{s c}$ & 12.53 & - & - & - & - \\
\hline & $L_{50}$ (Maturity Scale) & 13.05 & 1 & 0.106 & 12.82 & 13.27 \\
\hline & $L_{50}\left(G_{\mathrm{SI}} \%\right)$ & 13.76 & 0.677 & 0.254 & 13.23 & 14.29 \\
\hline
\end{tabular}




\section{Discussion}

Huxley's allometric equation $\left(y=a \cdot x^{b}\right)$ is widely used in studies of animal growth (Froese, 2006; Freitas et al., 2015), but presents clear constrains to describe the length/weight relationship as it assumes constant descriptive parameters during the entire ontogenetic development (Swain \& Foote, 1999). Once identified this problem, Bervian et al. (2006) developed a statistical model that considered possible changes in the growth pattern over time.

In the catfish $A$. longimanus, the change in the growth pattern identified as the stanza changing length $\left(L_{s c}\right)$ was close to the estimated onset of reproductive activity $\left(L_{50}\right)$, which occurs in males at a body length of around 11.5$12.0 \mathrm{~cm}$ and in females at approximately $13.0-13.8 \mathrm{~cm}$. This transition may be due to a shift in the pattern of individual energy investment reflected in the length/weight relationship.

For males A. longimanus, a shift from a negative allometry $(b=2.88)$ to a positively allometric coefficient $(b=3.18)$ suggests that energy acquired as immature juveniles is invested mainly in length body growth. This may reflect the need to grow-up faster in order to increase a competitive advantage in relation to other males in terms of female access. Once males have reached a minimum size for reproduction, the second stanza begins, in which energy is carried-out to weight growth and accumulation of fatty reserves.

The opposite pattern was observed in the females. In the first stanza, prior to the onset of reproduction, the females invest energy to weight increase (positive allometry: $b=$ 3.22 ), wears once the reproductive engagement is achieved, this pattern is modified by the loss of body mass through spawning (negative allometry: $b=2.95$ ). A similar pattern was recorded in Parauchenipterus striatus by Araújo et al. (2000), in which females were heavier than males up to the $15 \mathrm{~cm}$, but with an inverted trend above this body length. For Parauchenipterus galeatus, in contrast, Andrian \& Barbieri (1992) recorded just the opposite, suggesting no standard pattern for Auchenipteridae and the need of additional investigation.

The different approaches to the assessment of the minimum size at first maturity $\left(L_{50}\right)$ in males of $A$. longimanus, including the stanza changing length $\left(L_{s c}\right)$ of the polyphasic growth model, presented equal statistical results. However, for females these methods produced divergent results. Though, in general, in all three methods females matured at larger sizes than males, a pattern found for most teleosts (Helfman et al., 1997). This study also corroborate the methodological approach that estimate the size at first sexual maturity from $G_{\mathrm{SI}}$ values, as proposed by Fontoura et al. (2009). However, the approach appears to be conservative, given that it provided slightly higher estimates of $L_{50}$ in comparison with the usual methods.

Concluding, the shift in the growth pattern of the siluriform $A$. longimanus, as revealed by the stanza changing length $\left(L_{s c}\right)$, appears to be an useful marker of reproductive phase, as already described for a perciform species (Bervian et al., 2006) and characids (Fontoura et al., 2010). However, as the $L_{s c}$ values were lower than those estimated for $L_{50}$, the shift in the growth rate may represent a process of adjustment of physiological parameters for the incoming sexual maturation. Also, considering the large set of available information concerning length/weight relationship of fish (Oliva-Paterna et al., 2009; Joyeux et al., 2009; Freire et al., 2009), estimates of the stanza changing length of the polyphasic growth model may be used as an additional method for signalizing size at first maturity when no other information is available.

\section{Acknowledgements}

We are grateful to Benedito Brazão and Renato Calisto for the field assistance. We also thanks the Fundação O Boticário de Proteção à Natureza (process nº 0799/20082), the Programa de Pesquisa em Biodiversidade (PPBio/ Caxiuanã) and $\mathrm{CNPq}$ for financial support. We also thank CAPES, for its financial support through the Programa Nacional de Cooperação Acadêmica (PROCAD/UFPA; process $\mathrm{n}^{\mathrm{o}}$ 23038.042984/2008-30) and the Estação Científica Ferreira Penna (ECFPn/MPEG) for logistical support.

\section{References}

Andrian, I. F. \& G. Barbieri. 1992. Relação peso total/comprimento total e fator de condição do cangati, Parauchenipterus galeatus Linnaeus, 1766 (Siluriformes, Auchenipteridae) da região do reservatório de Itaipú, PR. Revista Unimar, 14: 177-191.

Araújo, F. G., S. Duarte, R. S. Goldberg \& I. Fichberg. 2000. Ciclo reprodutivo de Parauchenipterus striatulus (Pisces - Auchenipteridae) na represa de Ribeirão das Lajes - RJ. Arquivo Brasileiro de Medicina Veterinária e Zootecnia, 52: 276-284.

Bervian, G., N. F. Fontoura \& M. Haimovici. 2006. Statistical model of variable allometric growth: otolith growth in Micropogonias furnieri (Actinopterygii, Sciaenidae). Journal of Fish Biology, 68: 196-208.

Ferraris Jr., C. J., R. P. Vari \& S.J. Raredon. 2005. Catfishes of the genus Auchenipterichthys (Osteichthyes: Siluriformes: Auchenipteridae). Neotropical Ichthyology, 3: 89-106.

Fontoura, N. F. \& M. R. Conter. 2008. Description of a new subspecies of the crayfish Parastacus brasiliensis (Von Martens, 1869) from São Francisco de Paula, RS, Brazil (Decapoda, Parastacidae). Zootaxa, 1849: 28-34.

Fontoura, N. F., A. S. Braun \& P. C. C. Milani. 2009. Estimating size at first maturity $\left(L_{50}\right)$ from Gonadossomatic Index $\left(G_{\mathrm{SI}}\right)$ data. Neotropical Ichthyology, 7: 217-222.

Fontoura, N. F., A. S. Jesus, G. G. Larre \& J. R. Porto. 2010. Can length/weight relationship predict size at first maturity? A case study with two species of Characidae. Neotropical Ichthyology, 8: $835-840$ 
Freire, K. M. F., G. R. A. Rocha \& I. L. Souza. 2009. Length-weight relationships for fishes caught by shrimp trawl in southern Bahia, Brazil. Journal of Applied Ichthyology, 25: 356-357.

Freitas, T. M. S., B. S. Prudente, V. A. Oliveira, M. N. C. Oliveira, E. G. Prata, H. Leão, \& L. F. A. Montag. 2015. Influence of the flood pulse on the reproduction of Tocantinsia piresi (Miranda Ribeiro) and Auchenipterus nuchalis (Spix \& Agassiz) (Auchenipteridae) of the middle Xingu River, Brazil. Brazilian Journal of Biology, 75: 158-167.

Froese, R. 2006. Cube law, condition factor and weight-length relationships: history, meta-analysis and recommendations. Journal of Applied Ichthyology, 22: 241-253.

Froese, R. \& C. Binohlan. 2000. Empirical relationships to estimate asymptotic length, length at first maturity and length at maximum yield per recruit in fishes, with a simple method to evaluate length frequency data. Journal of Fish Biology, 56: 758-773.

Helfman, G. S., B. B. Collette \& D. E. Facey. 1997. The diversity of fishes. Oxford, Blackwell Science, 544p.

Huxley, J. S. 1924. Constant differential growth-ratios and their significance. Nature, 114: 895-896.

Joyeux, J. C., T. Giarrizzo, R. M. Macieira, H. L. Spach \& T. Vaske Jr. 2009. Length-weight relationships for brazilian estuarine fishes along a latitudinal gradient. Journal of Applied Ichthyology, 25: 350-355.
Le Cren, E. D. 1951. The length-weight relationship and seasonal cycle in gonad weight and condition in the perch (Perca fluviatilis). Journal of Animal Ecology, 20: 201-219.

Oliva-Paterna, F. J., M. Torralva \& E. D. Carvalho. 2009. Lengthweight relationships for 20 species collected in the Jurumirim reservoir (Paranapanema Basin, Brazil). Journal of Applied Ichthyology, 25: 360-361.

Strauss, R. E. 1993. The study of allometry since Huxley. Pp. 47-75. In: Huxley, J. S. (Ed.). Problems of relative growth. Baltimore, The Johns Hopkins University Press.

Swain, D. P. \& C. J. Foote. 1999. Stocks and chameleons: the use of phenotypic variation in stock identification. Fisheries Research, 43: 113-128.

Vazzoler, A. E. A. M. 1981. Manual de métodos para estudos biológicos de populações de peixes: reprodução e crescimento. Brasília, CNPq, Programa Nacional de Zoologia, 108p.

Zar, J. H. 2009. Biostatistical Analysis. New Jersey, Prentice-Hall, 960p.
Submitted September 21, 2015

Accepted August 24, 2016 by Clarice Fialho 
